\title{
Kommentar
}

af Gorm Harste

\section{I begyndelsen var (m)ordet}

\section{Bag forestillingen om "religionskrig" skjuler sig en anden konflikt, kampen om global kommunikation}

Børnelærdommen og fortidens idéer om gammeltestamentelige spørgsmål er pludseligt gjort aktuelle. Det er politisk næsten lige så overraskende som terroren den 11. september og Vestens efterfølgende militære afmagt. Religionsspørgsmål er kommet ind med en relevans, der ikke længere er forskudt til et marginalt kirkeministerium eller optræder som blot forspil til julens gaveregn. Religion sætter pludseligt, igen, den politiske dagsorden - som for 4-500 år siden.

Allerede for en overfladisk betragtning er der ikke grund til at antage, at terroristerne blot er smittet af et irrationelt religiøst vanvid. Er man opmærksom på de deklarationer, som Bin Laden og hans ledsagere har fremsat, og på det faktum, at terroren er organiseret i netværk af op mod flere hundrede mennesker, er det usandsynligt, at der blot er tale om "gale mennesker" - "insane people". Men vi er vant til at antage, at de velorganiserede ledende nazister var eller blev vanvittige $^{1}$. I begge tilfælde er der tale om grupper af mennesker, der har været igennem kulturelt uhyggeligt undergravende krige, henholdsvis Afghanistans uendelige borgerkrig og 1 . Verdenskrig, i hvis moralske helvede ingen socialpsykologisk forskning endnu har fået overblik. Der kan med andre ord være årsager til vanviddets raseri, og de kan findes i hjertet af Europa og USA såvel som i den 3. verden.

Men terroristerne fra 11. september synes ikke selv berørt af dette "insanity". De var tilsyneladende veluddannede storbymennesker. Min påstand er, at rationalet i deres vanvid består i, at deres terror viser den kortslutning, der opstår når mennesker udsættes for det moderne kommunikationssamfunds dobbelte måde at ekskludere på (Luhmann 2002; Castells 2000:135):

For det første kan man kortlægge baggrunden for den "irritation" "Amerika" i mere eller mindre grad udgør for resten af verden. Et vigtigt aspekt er her, at unge mennesker udsættes i dag for et uendeligt overfladisk "amerikaniseret" kultu- 
relt bombardement, der kan få de fleste religiøst musikalske mennesker til at blive fundamentalt skeptiske på den amerikaniserede kulturs vegne ${ }^{2}$ (Luhmann 1995; Castells 2000:135). Den dybere mening med moderne kommunikation optræder her let som falsk mammon og som blasfemisk bespottelse. For enhver med et minimum af oplysningstidens dannelsesidealer i behold vil erstatningen af Biblens og Koranens ord med Dallas, Dollars etc. med gode grunde kunne opleves som kulturel udtynding og forfald ${ }^{3}$.

For det andet bliver netop den 3. verden udsat for, at kommunikationssamfundets velsignelser ligger håbløst uden for rækkevidde. Min diagnose er, at den dobbelte afvisning, specielt af fattige, men uddannede storbyeliter, og specielt i islamiske kulturer, berører så påfaldende dybe lag i moderne samfunds udvikling, at vi befinder os i et kulturpolitisk ragnarok ${ }^{4}$.

Der kan også findes enkle rationelt forståelige grunde til terroren. Deklarationerne med krav om USAs tilbagetrækning fra Den arabiske Halvø og fra Iraks luftrum såvel som Israels fra ulovligt besatte områder, synes mulige genstande for rationelle forhandlinger og muliggør omgående indfrielse. Tilsyneladende. Problemet er imidlertid, at hverken USA, Israel eller verdenssamfundet kan acceptere, at en terrorakt får umiddelbar succes. Det ville skabe en næsten svimmelagtig effekt på igangsættelse af fremtidige terrorhandlinger. Hvor berettigede kravene end synes at være for de underkuede arabiske befolkningsgrupper.

Bag dette kan man imidlertid iagttage en grundlæggende konflikt om grundlaget for den moderne verden ${ }^{5}$. Forskellige forslag har været fremme: Konflikt mellem civilisationer ${ }^{6}$, religionskrig, korstog/jihad, os mod dem, rige mod fattige, herskende mod undertrykte osv. ${ }^{7}$

Spørgsmålet er, om man kan sammen- fatte konflikterne i én enkelt formel? Og problemet er, at selv om vi vil svare benægtende, nytter det ikke noget, hvis andre modsatrettede grupper svarer bekræftende, at der er én formel. Hvad er det, der gemmer sig i dét problem? Hvor grundlæggende må vi gå til værks med bearbejdningen af vores kulturarv, vores fortid og vores samtid?

Det er uhyre vigtigt at være opmærksom på, at Islam, Jødedom og Kristendom har én og samme oprindelse. Der er tale om én og kun én Gud; der er endog tale om den samme Gud, Abrahams Gud. Der er tale om bog-religioner: Koranen, Det gamle Testamente, Det nye Testamente. Og fordi der er tale om én Gud og den samme Gud, er der også tale om én verden og kun én og samme verden (Luhmann 1977: 40-42). Der her drejer sig om Gud, Teksten og Verden ${ }^{8}$.

Dén konstatering har skrækkeligt mange konsekvenser. For det første bliver vi på begge sider af Middelhavet uhyre ømfindtlige over for, hvad der gøres til den herskende dagsorden. Specielt galt går det, når der som de seneste 10-15 år er tale om, at dagsordenen hedder "globaliseringen", som om der kun var tale om én eneste trend her i verden (Barber 1995). Når vestlige politikere og medier påstår, at globaliseringen er en enhed, og at den rammer os alle, rokker den ved en grundlæggende forestilling om, at der skulle være sammenhæng i verden ${ }^{9}$.

Det er en metafysisk og oprindeligt religiøs forestilling, der eksempelvis har sin parallel til forestillingen om ét verdenscenter, en forestilling, der på det seneste forbavsende hurtigt har forskudt sig fra World Trade Center tilbage til Jerusalem ${ }^{10}$.

For det andet: Bog-religionerne er alle forbandet opmærksomme på, hvad der foregår med tekster, med sprog, tegn og kommunikation ${ }^{11}$. Bog-religionerne opstod, fordi talesproget fik en modpart i 
tekstsproget, der kunne gøres evigt gældende på tværs af tid, sted og personer. Og fordi der med antagelsen om kun én verden hævdedes et skel mellem væsentlige tekster og mindre væsentlige tekster.

For det tredie: Middelhavet og Romerriget var den verden, der var gældende (Mann 1986:kap. 10). Men dén enhed forsvandt til fordel for en forestilling om en egentlig åndelig verdenssammenhæng. Efter Romerrigets sammenbrud spaltedes de tekstsamlinger, der ansås for de væsentligste, og vi fik de tre bog-religioner, hvis konturer faktisk først blev klare hen mod det 7. og 8. århundrede og endda senere, idet den territoriale afgrænsning vel først kan siges at stamme fra korstogstiden, som førte til opfindelsen af Europa og Vesten. Tilsvarende blev alle tre religioner delt i mere eller mindre bogstavtro sekter.

Accelerationen i Vestens rationalitet begyndte formodentligt med en bearbejdning af tekster, nemlig i forsøget på at indtolke romersk domsret i en Bibelsk helhed (Berman 1983:kap. 3). Teorier og eksperimenter med love for mennesker, naturen og Gud opstod. Et var tekster, noget andet var fortolkningssammenhængen. Tekstens bogstav og dens (hellige) ånd blev adskilt (Luhmann 2000: 328-335). Teksterne kunne fordeles rundt, mens den hellige ånd kunne forene de, der anvendte teksterne. På begge sider af Middelhavet skabte det fantastiske organiseringsmuligheder i en tid, hvor telefoner, postvæsen og internet ikke fandtes, og sejlads på Middelhavet endda var farefyldt.

Nu skal vi huske, at historiesynet, altså synet på historiens længde, epoker, forskelle, tyngde og betydning opfattes vidt forskelligt i verden. Højt uddannede har et andet syn end lavt uddannede, nordeuropæere et andet syn end f.eks. italienere; europæere et andet end amerikanere; jøder atter andre; og kinesere, japanere, arabiske grupperinger igen andre. Hvad der er fjern fortid for os, kan være ganske nært for andre (Koselleck 2000:168-202).

Når historikere taler om "religionskrige $^{\prime \prime}$, henviser de normalt til 15- og 1600tallets krige mellem protestanter og katolikker (Livet 1996). Hvad har de med sagen at gøre? Jo, det dybest set egentligt ganske chokerende er, at de opstod som - semiotiske - konflikter om kommunikation, tegns mening og betydning (Juanna 1996:306ff). På den ene side om samfundets grad af centralisering og decentralisering og på den anden side om, hvorledes ordnen kunne ordnes ved hjælp af kommunikation, og det er her, det religiøse kom ind: Problemet var, at trykpressens anvendelse fra slutningen af 1400tallet gjorde optryk af Bibler og Bibel-fortolkninger i store oplag mulige (Eisenstein 1983:92ff; Brunkhorst 2000:58). Mange blev skriftkloge, og der opstod nye typer skriftanvendelser, love, atlas, sedler, romaner, videnskabelige skrifter etc. Det skabte tre reaktioner:

Nogle mente, at man skulle fastholde den gamle brug af sprog, fortolkning og tekst knyttet til, at kommunikation først og fremmest foregik i konkrete møder, med nadveren - Jesus og de 12 disciple som den altoverskyggende grundmodel for datidens organisation og management $^{12}$ - og mødekoncept: Bønnen, ritualet, ordenes gentagelse sikrede deres virkelighed; ord var ikke bare tilfældige, og de repræsenterede ikke verdens virkelighed på nogen ydre og vilkårlig måde. Så denne - katolske - strømning forsøgte enten at reagere konservativt ved at fastholde det forældede eller ved at foretage en opstramning og oppumpning af ritualerne. Det er fra denne "kontrareformation", de pompøse katolske kirker stammer.

Lutheranerne i Midteuropa fastholdt fællesskabet om tekster, men også mulig- 
heden for at de kunne fortolkes forskelligt (Pallesen 2001). Teksten blev mere central, og fælles, og derudover var der "mig og Gud". Specielt hos lutheranerne ses forskellen til Jødedom og Islam, da Kristus udgør forskellen. Hvorfor det? Hvilken symbolik ligger der i Kristus? I nadverlæren var Kristus symbolet for chefen og for helligåndens og korpsåndens enhed, men i luthersk inspirerede udlægninger blev Kristus til individet, der gør forskellen til fortiden, og Kristi ord til det ord eller den tekst, der adskiller sig fra konteksten: Ordet adskilles fra virkeligheden, for dermed - fremtidigt - at håbe at kunne skabe en ny og anden virkelighed. Dermed er skæbnen beseglet. Biblens, tekstens og kommunikationens nyvundne lethed fordrede, at individet var parat til at tage kampen op mod sig selv. Kommunikationens lethed fordrede individualisering.

Kalvinisterne i Vestens handelsbyer nøjedes da også med at sidde individuelt og læse Biblens ord for så at gøre deres aktivitet og virke til garantien for, om de hørte blandt de udvalgte, $i$ en protestantisk arbejdsetik. Guds orden skulle indsættes her på jord, i et andet medie end kirkens.

Denne rationelle realisering af orden og mening har haft så stor betydning også for de lutherske og katolske strømninger - at kristendommen ikke længere har brug for, at vi tror på den for at realisere sine bud, skel, differentieringer og koder. Et eksempel: Hvor islam lige som Vesten indtil 1920'erne kræver tildækning af kroppen for at styre sanserne og begæret, er det netop samtidigt med, at ateismen går sin sejrsgang blevet muligt for den enkelte at udstille, hvilken uhyre sikker kontrol han eller hun har over sin krop ved at optræde næsten nøgen på badestrandene: Når kroppene afdækkes bliver blikkene tildækkede, som Erwing Goffman siger. Kristendommen har ud over alle grænser næsten sejret sig selv til døde.

Vesten afprøver og afsikrer sin tro så langt uden for kirkens hellige steder og $\mathrm{i}$ så anderledes medier og sammenhænge, at de fleste har glemt, hvad baggrunden for denne uendelige bestræbelse på ordensskabelse på arbejdspladser, badestrande og det offentlige liv var ${ }^{13}$. Til stor og til tider uendelig forvirring for de fundamentalistiske, fra Søren Krarups til Bin Ladens tilhængere. Den stadigt mere globaliserede kommunikation koketterer med lette adgange, men tildækker sine åbninger i en sådan grad, at vi igen kan siges at leve i et stændersamfund.

I 1500-tallet havde vi en kommunikationsrevolution og en række efterfølgende religionskrige. Efter oplysningstidens industrialisering og billiggørelse af kommunikation og uddannelse fik vi opsplitning og klassekonflikter mellem ny-kalvinske liberalister, ny-katolske konservative og solidaritets-orienterede partier, og ny-lutheranske retsliberale (Eder 1985:125ff). Nationalisme, kommunisme og liberalistisk egoisme blev de nye sekter (Harste 2001).

Med de seneste årtiers telematiske revolution af kommunikation gentages konflikterne om kommunikationens vilkårlighed og verdens realitet. Tilsyneladende kan alt lade sig gøre i telematikkens cyber-realitet - og hvor bliver virkeligheden så af? Alt kan kommunikeres, billedliggøres, omtales, fordrejes, fornedres, gøres til kærlighed, skrækfilm, begær, lyst, sandhed og løgn, livsmål og rejsemål, ret og uret - i symbolproduktionens virkelighed. Læg mærke til, at WTC-angrebet på den ene side foregik i Østarabisk prime-time og på den anden side udstillede et klassisk religiøst mirakel, hvor symbol bliver til virkelighed: "Hvis amerikanerne vil se katastrofefilm, godt, så skal vi give dem katastrofer at se på“" synes terroristerne at have tænkt. Terro- 
risterne var storbymennesker udsat for kommunikationens amerikaniserede flimmer og samtidigt ekskluderede fra det velsignede netværkssamfund, - og det er her kæden hopper af: Den amerikaniserede kommunikationsverden lover alt i nærmest repetitive fremstillinger af sin egen herlighed, men lukker de håbefulde ude, vel at mærke på et "falsk" og "ugudeligt" grundlag, uden legitimitet og uden anden autoritet end kulturfortyndelsens.

Netop i den rituelle gentagelse, i koblingen mellem bøn, ofring og en ihærdigt kæmpende bestræbelse transformeres symboler til substans - på to forskellige måder: I den gamle katolicisme og endnu hos Europas, USAs og arabiske landes anti-moderne befolkningsgrupper fastholder man symbolers hellighed - pis på Dannebrog og se, hvad nationalisterne siger til det! Afbrænding af ikonet Stars and Stripes synes lige så rituelt gennemført som MacDonaldiseringen af verden hævdes med en alt-globaliserende ret.

Jordens ene supermagt kan fastholde sit tag over verden ved hjælp af IT, internet og satelitter; den nye "verdensmagt" bruger helligånden og synkroniserer sine bevægelser trådløst med en mindst lige så høj grad af evne til at decentralisere sine politiske, organisatoriske og militære bevægelser som USA. Jo mere voldsomt USA betjener sig af sine klassiske militær-industrielle midler, des stærkere bliver den anti-moderne bevægelse, indtil det punkt, hvor amerikanere selv begynder at handle anti-moderne og ofre deres liv for fædrelandet. Jo flere burgers, des flere bål, indtil amerikanerne selv så at sige begynder at brænde indvendigt - og brænde tekster som i en gentagelse af 1950'ernes kommunistforskrækkede McCarthyisme.

Over for denne stereotypificering af et amerikaniseret McWorld kan man selv- følgelig indvende tre ting: At USA empirisk er mangefacetteret og i øvrigt - med frem for alt New York - er en af de mest multikulturelle nationer i verden; at en supermagt, det være sig Romerriget, Frankrig i 1600- og 1700-tallet; England i 1800-tallet for ikke at sige Tyskland i 1940 'erne og Sovjet eller Kina, altid ville markere sig i omverden med klichéagtige koder, der reducerer en kulturel kompleksitet og fremstiller kultur som farce eller tragedie. Og at USA for det tredje derfor ikke er den værste supermagt, verden kunne udsættes for. Supermagten indtager autoritetens rolle i individets og subkulturernes over-jeg og får derfor skyld og ansvar ud over al rimelighed. Alligevel kan man sige, at vi nu for første gang sociologisk set har et "verdenssamfund" (Moe 2001) ${ }^{14}$, der så udsættes for én og kun én globaliseringsstrategi: McWorlds.

Holder denne diagnose, synes der dog at være udveje frem for genoptagelsen af gammel-religiøse kommunikationskrige. Der er tre-fire aspekter.

For det første må folkeretseksperter og forhandlere i internationale organisationer være opmærksomme på, at det vestlige grundlag for interstatslige relationer blev skabt i konsekvens af religionskrigene, nemlig i 1648 med Den westphalske Fred efter 30-årskrigen. Det er således påfaldende, at datidens store folkeretlige værk, den hollandsk-fransk-svenske teolog, jurist og diplomat Hugo Grotius' Om Krigens og Fredens Ret fra 1625, i bund og grund forsøgte at vise betydningen af, at der bag om forskellige religiøse tolkninger og uenigheder om retsgrundlag også er et fælles retsgrundlag - hvormed Den westphalske Orden senere kunne skabes (Grotius 1999:kap. 2).

Denne bestræbelse på at gå bag om forskellige tekstudlægninger for at se ligheder og paralleller er formodentlig en del af såvel problemet som løsningen på nutidens konflikt. Forestillinger om "ret- 
færdig krig"(jus ad bellum) og "jihad" som "ret til kamp" går således bag om korstogene og bag om maurernes erobring af Spanien i 700-tallet og de myter, der er knyttet dertil, helt tilbage til gammeltestamentelige kodificeringer i Mose-bøgerne (specielt 5. Mosebog)(Flori 2001; Delfort 1988; Harste 2002). Vi må bag om kristendommen og dens retstradition: Suverænitet, territorialitet, respekt, intervention og ikke-intervention skal og må samtolkes med ikke-vestlige standarder; og der er gode grunde til, at det kan lade sig gøre, omend det er sejt arbejde. Grotius inddrog eksempelvis Jødedommen og Det gamle Testamentes beskrivelse af Israels territorialitet; men han tog desværre ikke islamisk ret og Koranen i betragtning.

For det andet er dogmet om globaliseringens enhed et problem. Ikke mindst politikere og journalister taler ustandselig om globalisering som en enhed og én bevægelse. Men det er en dødsensfarlig myte (Harste 1990; Kaspersen 2001). Der er mange tendenser i dag, enkelte er globale, andre regionale, og mange lokale (Hirst \& Thompson 1996; Hirst 1997). Globaliseringer går i flere retninger, men ikke de samme: Økologisk globale hensyn er yderst sammensatte; økonomisk set er globalisering ikke ny og er så sammensat, at der ikke kan tales om en sammenhæng; politisk er billedet også meget mere komplekst med mange tusinder regionale organisationer, der hverken er statslige eller globale. Den "globaliserede" videnskab er stort set et europæisk-amerikansk foretagende. Men er der én globalisering, er der også kun én trend i fordelingen af rigdom, adgange, inklusion - og eksklusion. Ergo: Stop myten om globaliseringen. Den skaber en risiko for, at verdensbilleder og dermed trosforhold gøres mere ustabile, end der er grund til.

Pointen er netop ikke, at muslimer skulle befinde sig $i$ en anden verden end kristne, men at de bebor den samme verden. Religionskrigene foregik - som hos kommunister - mellem sekter, om den samme sag og, til dels, de samme tekster (f.eks. Mosebøgerne). Konflikten i dag er derfor mindre mellem religionerne end, som førhen, mellem de fundamentalt tekst- og symboltro mod de, der ser samfundets åbenhed som en åbenhed i fortolkninger (Goldzieher 1973).

For det tredje kan åbenlyse uretfærdigheder og misforhold mellem rige og fattige, magthavere og undertrykkere udbedres, og det debatteres og planlægges da også i disse måneder overalt.

Kommunikationens ulidelige lethed gennem de sidste årtier kan der også gøres noget ved. Selvom den er et faktum, er den også en læreproces. Det er imidlertid ikke nok at gå den halve vej i fortolkningen af symbolers bevægelighed. Nazismens anti-moderne religion opstod trods alt i Luthers Tyskland. En halveret modernitet kan skabe en uhyggelig trang til "Rückkehr", tilbagevending netop blandt moderniserede unge.

Det er på ingen måde uforudsigeligt, at den globaliserede modernitet har ført til et kulturpolitisk ragnarok. Den fremtrædende tyske sociolog Max Weber påpegede allerede i begyndelsen af 1900tallet, at Vesten gennemrationaliserede en instrumentel-teknokratisk strategi uden at lade rationaliseringen af værdier følge trop, og at det ville føre til et sammenbrud i livsværdier. Siden har kulturaristokratiske sociologer som Theodor Adorno og postmodernisten Jean Baudrillard i deres bøger om amerikaniseringens pseudokultur påpeget konflikten med endnu større skepsis eller melankoli.

I stedet for at udbrede menings- og kulturfortyndende gimmicks er det en storpolitisk opgave at fremvise tyngden af Vestens kultur. I stedet for ligegyldigt 
og derfor blasfemisk pop er det livsnødvendigt at inddrage de ekskluderede unge, både nord og syd for Middelhavet, i den kulturhistoriske tyngde fra Bach til Bolsjoj og fra Dante til Eco, som vi jo også selv anvender, når vi ikke blot vil spises af med krummer fra de riges land. Når unge veluddannede muslimer, jøder og kristne ser og hører McWorlds amerikaniserede gøgl, må de vitterligt spørge, om det virkeligt var dét, tekst, tegn og symboler skulle bruges til. I stedet for blot at bygge ekslusive markeder og handelspladser, skal vi bygge inklusive universiteter, katedraler og operahuse. Må jeg minde om, at dengang de lokale eliter bevægede sig ud af de lokale religionskrige og skulle lære sig staternes og det moderne samfunds betydninger og symboler at kende i århundredet efter 1648, foregik det gennem universiteter, teatre, operaer, avanceret arkitektur og litteratur ikke med pop (Wilentz 1999). Kulturpolitik er storpolitik.

\section{Noter}

1. I Clark (1965) analyseres således en lang række dialoger mellem Hitler og hans generalstab, hvor kommunikationens og dialogens afsporing bliver stadigt tydeligere.

2. Slavoj Zizek har aktuelt påpeget denne kommunikative eksklusions-tekniks betydning for terroristernes symbolske markering af en gen-inklusion, der endda er foregået via de øverste etager af World Trade Center. De gængse kultursociologiske referencer til den kritik af "amerikansieringen" er Theodor Adorno (1951) og Jean Baudrillard (1987).

3. Inklusion/eksklusions-temaets kulturelle fortolkning er velkendt $i$ sociologien fra Norbert Elias' klassiske 1930-er studier (Elias 1969; 1976) til de kommunikations- og symbolteoretiske baserede gentolkninger hos Niklas Luhmann (1980; 1997; 618-634; 678826) og Pierre Bourdieu (1979; 1989).

4. Hos Luhmann (1995) analyseres med henvisning til den 3 . verdens storbyer, hvorledes en fordobling af inklusion/eksklusion indgår som en "re-entry" i skellet selv.
Zygmunt Bauman analyserer ligeledes en dobbelt eksklusion i Bauman (1997:28ff.); begge hæfter sig ved den betydningsopløsning, der foregår på eksklusionssiden.

5. Jf. Tibi (2001a og 2001b) hvis forord bl.a. behandler begivenhederne efter 11. september 2001, der omtrent forudsiges i bogen, som var skrevet før 11. september.

6. Huntingtons berømte tese (i Huntington 1996) er selvfølgelig langt mere kompleks end dens populære udlægning, idet han kort sagt forsøger at hævde tesen, at modernisering ikke nødvendigvis er lig "Westernization"; (spec. pp. 56-78). Bassam Tibi har fremlagt betydeligt mere dybtgående analyser af, hvorvidt der er tale om forskellige vestlige/arabiske civilisationer eller forskellige tolkninger inden for én og samme verden; kort fortalt går tolkningsproblemet på konflikten mellem politiseret fundamentalisme og en ny form for dialog eller kommunikativ rationalisering i Habermas' forstand (Tibi 2001a, 2001b).

7. I modsætning til alle andre (islamisk, kristne, retlige, moralske, militærteoretiske) tolkninger tager Carl Schmitts berygtede Det politiske begreb (2002) udgangspunkt i, at der skulle herske et symmetrisk forhold mellem ven/fjende, som er underlagt en vilkårlig beslutning. Det er epistemologisk nonsens, som forenkler historiens kompleksitet til et forplumret "klarsyn".

8. Hos Jean Bodin, 1576, er den kristne forestilling om én Gud det, der legitimerer hans teori om én suverænitet, en problematik, der blev afgørende for Hugo Grotius' grundlæggelse i 1625 af moderne folkeret mellem kristenhedens (og jødedommens) konger.

9. I den teologiske dogmatik optræder distinktionen mellem erfaringen af verden/ verden som en markeret enhed, der må adskilles fra de empiriske udbredelser af verdensreligioner i et "verdenssamfund" som "den kristne verden" eller "islamiseringen af verden"; jf. Luhmann 2000:29f:341.

10. "Verdenscentre" kan aflæses historisk ud fra kortlægningens historie. Den klassiske antikke kortlægning tog udgangspunktet $i$ verden som et $T$ indskrevet $i$ en cirkel, et $\mathrm{O}$, hvor Asien var over barren i T'et og Europa nederst til venstre, mens Afrika var nederst til højre, verdensfloderne Nilen og Don udgjorde barren og Middelhavet stolpen i T'et. Jerusalem blev da så at sige til 
prikken over T'et (Brotton 1997:29). Fra europæisk kortlægningstradition ved vi selvfølgelig, at Europa var centrum, under den kolde krig var Berlin således Verdens omdrejningspunkt.

11. Johannes-evangeliets begyndelse lader ordet begynde. Tilsvarende formulerer $\mathrm{Mu}$ hammed i Koranen (Blachère 1966) i Sourate $\mathrm{V}$, vers 99 at "A l'Apôtre n'incombe que la Communication", apostlen er blot talerør i kommunikationen. Den grundlæggende filosofi om problemstillingen findes $i$ Augustins Bekendelser fra omkring 400 (Augustin 1988:kap.11), hvor Augustin dialogiserer med ingen ringere end Gud om, hvorledes han tror at kunne overtage sproget som arv. (Den norske oversættelse formulerer pradokserne heri fagligt langt klarere).

12. Koranen indeholder næsten helt parallelle modeller for brugen af tekst, tro og Guds/Allahs ord i et fællesskab, hvis udsendinge ledes af ordets fortolkning, f.eks. Sourate II, 209/213 i Koranen (Blachère 1966:59).

13. Således skriver Max Weber: "Den kristne askese, der i begyndelsen flygtede ud af verden og ind i ensomheden, ind i klostret, havde allerede herfra behersket verden ved hjælp af kirken. Men derved havde den i det store og hele ladet det verdslige hverdagslivs naturlige frimodige karakter være uberørt. Nu [efter 1500-tallet] trådte den ind på livets markedsplads, lukkede klosterdøren bag sig og tog fat på at gennemtrænge netop det verdslige hverdagsliv med sin metodik, idet den ville omforme det til et rationelt liv i denne verden“(1995:102).

14. Rudolf Stichweh skelner således på baggrund af Luhmanns systemteori mellem "verdenssamfundet" og mekanismer for "globalisering"; jf. Stichweh (2000). "Verden" iagttages her som en åbning af horisonter, mens globalisering operationelt lukker sine koder for omverdenens betydninger. Jf. Luhmann (1975: 51ff); Luhmann (1997: 809).

\section{Litteratur}

Adorno, Theodor 1951: Minima Moralia, Aarhus: Modtryk (1987).

Augustin 1988: Augustins bekendelser. København: Ansgars Forlag.

Barber, Benjamin 1995: Jihad vs. McWorld. New York: Times Books.

Baudrillard, Jean 1987: Amerika, København: Akademisk Forlag.

Bauman, Zygmunt 1997: Globalisering. København: Hans Reitzel.

Berman, Harold 1983: Law and Revolution. The Formation of the Western Legal Tradition. Camb.Mass: Harvard Univ. Press.

Blachère, Régis (ed.) 1966: Le Coran. Paris: Maisonneuve.

Bourdieu, Pierre 1979: La distinction. Paris: Minuit.

Bourdieu, Pierre 1989: La noblesse d'état. Paris: Minuit.

Brotton, Jerry 1997: Trading Territories. Mapping the early modern world. London: Reaktion Books.

Brunkhorst, Hauke 2000: Einleitung in die Geschichte politischer Theorien. München: UTB.

Castells, Manuel 2000: The Rise of Network Society. Oxford: Blackwell.

Clark, Alan 1965: Barbarossa. The RussianGerman Conflict 1941-45. London: MacMillan.

Delfort, Robert (ed.) 1988: Les croisades. Paris: Seuil.

Eder, Klaus 1985: Geschichte als Lernprozess? Frankfurt: Suhrkamp.

Eisenstein, Elizabeth 1983: The Printing Revolution in Early Modern Europe. Cambridge University Press.

Elias, Norbert 1969: Die höfische Gesellschaft. Berlin: Luchterhand (opr. 1933).

Elias, Norbert 1976: Über den Prozess der Zivilisation, Bd.1-2. Frankfurt: Suhrkamp (opr. 1939).

Flori, Jean 2001: La guerre sainte: La formation de lidée de croisade dans l'Occident 
chrétien. Paris: Aubier.

Goldzieher, I. 1973: Le dogme et la loi de l'islam. Histoire du développement dogmatique et juridique de la religion musulmane. Paris: Geuthner (opr. Tysk 1910).

Grotius, Hugo 1999: Le droit de la guerre et de la paix. Paris: PUF.

Harste, Gorm 1990: "Store fortællinger lever og har det godt", i Jens F. Jensen (red.): Computer-kultur, Computer-medier, Computer-semiotik. Aalborg: Nordisk Sommer Universitet.

Harste, Gorm 2001: “Fra Helligånd til Internet - Individets kommunikationsbetingelser" i Peter Rosendal Frederiksen m.fl. (red.): Individualitet, Fællesskab, Værdier. Frederikshavn: Dafolo.

Harste, Gorm 2002: "Krigens sociologi, fredens idéhistorie - enhed og forskel“ i Rubicon, 10.årg, nr. 1, pp.731.

Hirst, Paul \& Thompson, Graham1996: Globalization in Question. Oxford: Polity Press.

Hirst, Paul 1997: "Globalisering er blevet moderne - men er det en myte?" $\mathrm{i}$ Globalisering, demokrati og det civile samfund. København: H. Reitzel.

Huntington; Samuel 1996: The Clash between Civilizations and the Remaking of World Order. New York: Simon and Schuster.

Kaspersen, Lars Bo 2001: “Globalskabens årti?" i Dansk Sociologi, 2001, nr. 1, pp. 83-86.

Koselleck, Reinhart 2000: Zeitschichten. Frankfurt: Suhrkamp.

Jouanna, Arlette 1996: La France du XVIe siècle. Paris: PUF.

Livet, Georges 1996: Les guerres de religion. Paris: PUF.

Luhmann, Niklas 1975: “Die Weltgesellschaft" $i$ Soziologische Aufklärung, Band 2. Opladen: Westdeutscher Verlag.
Luhmann, Niklas 1977: Die Funktion der Religion. Frankfurt: Suhrkamp.

Luhmann, Niklas 1980: "Interaktion in den Oberschichten" $i$ Gesellschaftsstruktur und Semantik, Band 1. Frankfurt: Suhrkamp.

Luhmann, Niklas 1997: Die Gesellschaft der Gesellschaft. Frankfurt: Suhrkamp.

Luhmann, Niklas 2000: Die Religion der Gesellschaft. Frankfurt: Suhrkamp.

Luhmann, Niklas 2002: "Inklusion og Eksklusion" i Distinktion nr. 4, s. 12140. Aarhus.

Mann, Michael 1986: "Ideology transcendent: The Christian ecumene" , kap. 10 i The Sources of Social Power Vol.1. Cambridge University Press.

Moe, Sverre 2001: "Verdenssamfunnet" i Dansk Sociologinr.2, 12.årg. 2001, pp. 63-76.

Pallesen, Carsten 2001: “Objectum fidei - Luthers nadverlære i systemteoretisk belysning" i Dansk Teologisk Tidsskrift 64.årg. 2001, pp. 16-44.

Stichweh, Rudolph 2000: "On the Genesis of World Society" i Distinktion nr. 1, pp. 27-38.

Tibi, Bassam 2001a: Krieg der Zivilisationen: Politik und Religion zwischen Vernunft und Fundamentalismus. München: Heyne Verlag (1995).

Tibi, Bassam 2001b: Die neue Weltunordnung. München: UTB.

Weber, Max 1995: Den protestantiske etik. København: Nansensgades Antikvariat (opr. 1905).

Wilentz, Sean (ed.) 1999: Rites of Power. Symbolism, Ritual and Politics since the Middle Ages. Philadelpia: Univ. of Pensylvania Press.

Gorm Harste

E-mail: GHA@ps.au.dk 